\title{
Acknowledgement
}

The project is financially supported by the Commission of the European Communities and by the Danish Natural Science Research Council.

\section{Observations on Upper Permian sediments in southern Scoresby Land, East Greenland}

\section{Lars Stemmerik}

Investigation of the Upper Permian sediments in East Greenland initiated in 1978 (Stemmerik, 1979) was continued during the field season 1979. The investigations were centred around Revdal and Schuchert Dal, but Oksedal, Depotø and Gauss Halvø were visited as well (fig. 36 ).

The deposits of Revdal are situated close to the western margin of the Permian basin,

Fig. 36. Distribution of Upper Permian sediments in East Greenland.

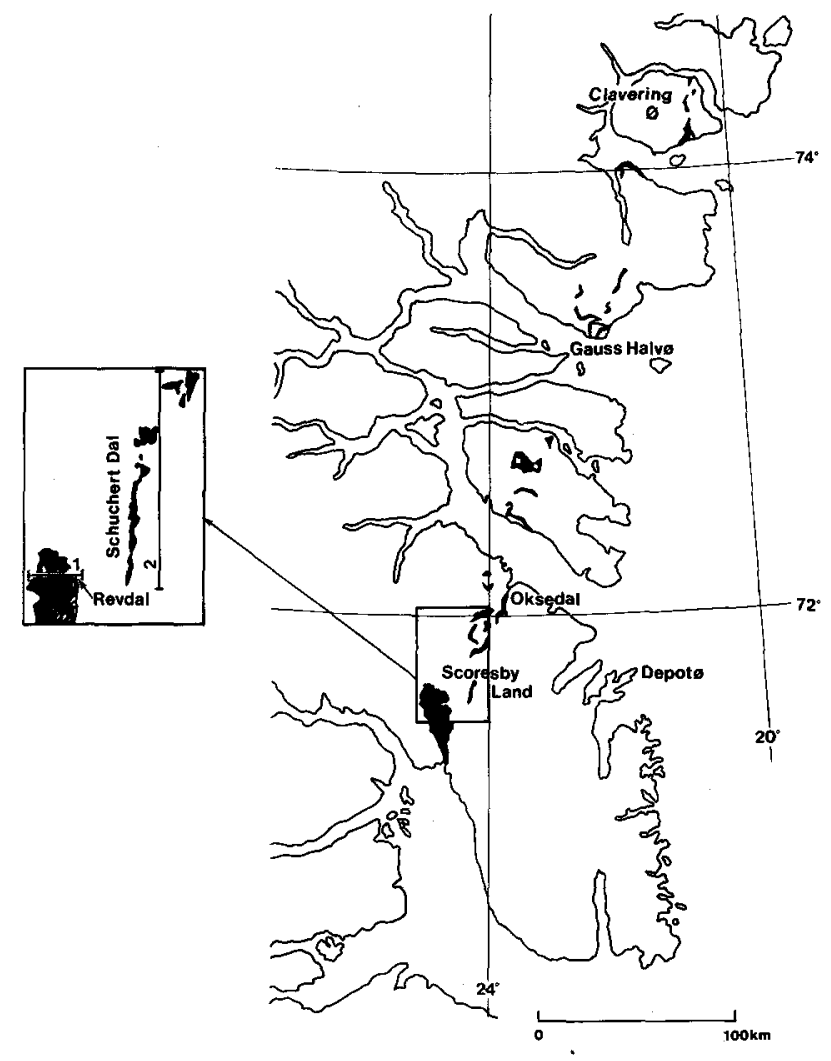




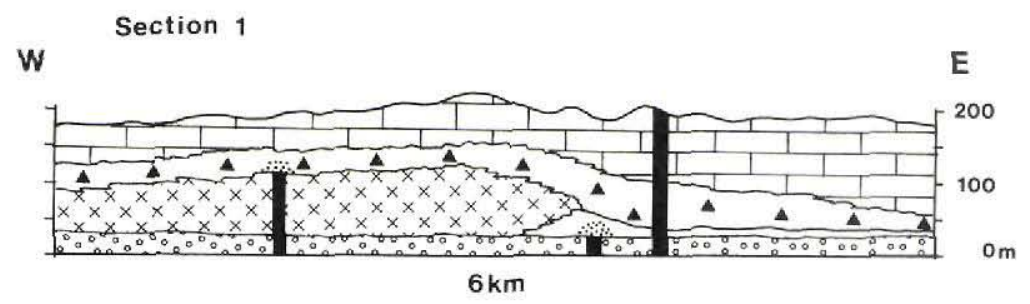

Section 2

N

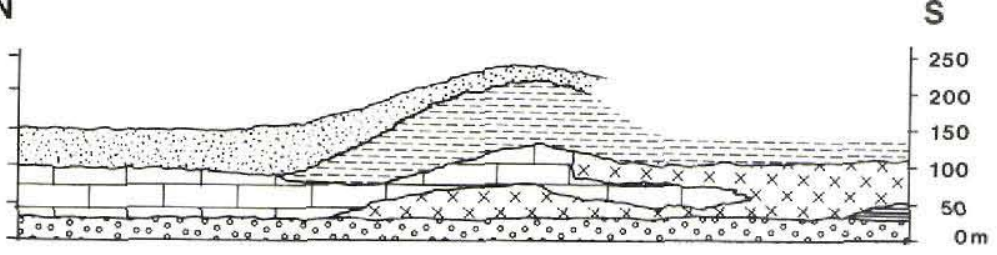

$25 \mathrm{~km}$
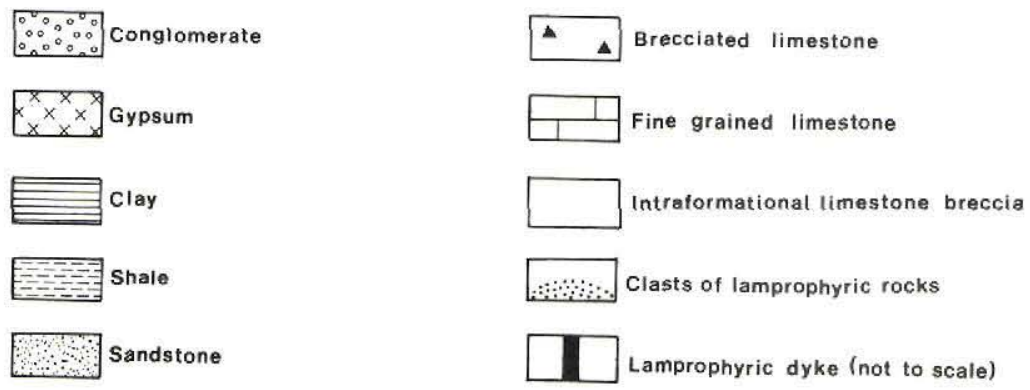

Fig. 37. Schematic sections showing the Upper Permian facies variation in southern Scoresby Land. Location of the sections are marked on fig. 36.

where Late Permian tectonism (Stemmerik \& Sørensen, this report) has affected the sedimentation. Correlation between immediately adjoining areas is thus difficult, and the only unit which can be directly correlated eastwards from Revdal is a conglomerate varying in thickness from 25 to $50 \mathrm{~m}$.

This Conglomerate Member of Maync $(1942,1961)$ forms the basal part of the Upper Permian sequence in the entire Scoresby Land area, where it uniformly rests on Lower Permian sediments with a slight angular unconformity. The conglomerate is totally dominated by granites, which are undoubtedly derived from the Caledonides immediately to the west and were deposited under fluviatile conditions. Locally, the uppermost half metre of the conglomerate contains a sparse, reworked marine fauna comprising spiriferid brachiopods and encrusting bryozoans of Late Permian age.

Two distinct areas of gypsum deposits may be distinguished (fig. 37). In Schuchert Dal the gypsum unit is dominated by rhythmically alternating dolomite and gypsum. Most of the sequence is finely laminated, but towards the top individual beds most commonly reach 50 
$\mathrm{cm}$ in thickness. In Revdal the gypsum is very pure and contains two, less than $3 \mathrm{~m}$ thick units of brecciated limestone overlain by stromatolitic limestone. Most likely the two units represent short events during which the deposition of gypsum was suppressed, as a result of brief connection to the adjoining sea. The more normal saline water, which probably swept the breccias into the area allowed algal growth to take place until hypersaline conditions were gradually re-established.

Where preserved the gypsum deposits were apparently bound by areas of carbonate deposition (fig. 37). In Revdal the lower part of the gypsum laterally passes into stromatolitic limestone overlain by a mud-supported limestone breccia similar to the breccia units in the gypsum. This intraformational breccia gradually passes up into breccias dominated by limestone clasts of unknown origin. These breccias are restricted to Revdal were they also overlie the gypsum (fig. 37). The deposition of the breccias are probably related directly to tectonic events in the margin of the basin.

In Schuchert Dal rhythmically laminated limestones and mudstones with a sparse brachiopod fauna dominate the limestone unit, indicating quieter depositional conditions. Somewhat similar mudstones are found in Revdal, where they constitute the remaining part of the Upper Permian sequence (fig. 37) and, locally comprise rich faunas of brachiopods, bryozoans and fusulinid foraminiferas.

Towards the end of the Permian the clastic influx gradually increased in the Schuchert Dal area. In the southern part black laminated Posidonia Shale overlies the limestone and gypsum whereas, in the north, fine-grained sandstone directly overlies the limestone.

\section{Acknowledgements}

The sedimentological investigations were carried out with the support of the Danish Natural Science Research Council (SNF), and this is gratefully acknowledged.

\section{Keferences}

Maync, W. 1942: Stratigraphie und Faziesverhältnisse der oberpermischen Ablagerungen Ostgrönlands (olim "Oberkarbon-Unterperm") zwischen Wollaston Forland und dem Kejser Franz Josephs Fjord. Meddr Gronland 115(2), 128 pp.

Maync, W. 1961: The Permian of Greenland. In Raasch, G. O. (edit.) Geology of the Arctic 1, 214-223. Toronto U.P.

Stemmerik, L. 1979: Observations on the Upper Permian of Wegener Halvø, East Greenland. Rapp. Grønlands geol. Unders. 95, 90-92. 